\title{
Water retention of the loess-derived Luvisols with lamellic illuvial horizon in the Trzebnica Hills (SW Poland)
}

\begin{abstract}
The aim of work was to characterize the water retention in the silt-textured Luvisols with lamellic illuvial horizon (argic) that occur in the loess covered northern part of the Silesian Lowland. Soil pits were localized on the Trzebnica Hills near the villages: Machnice (profile 1), Skarszyn (profile 2) and Zaprężyn (profile 3 and 4). Profiles Machnice 1 and Skarszyn 2 were situated in the upper parts of the hills covered with beech stands with an admixture of oak, linden and maple. Profiles Zaprężyn 3 and 4 were situated in the central and lower parts of the arable slope. During the field work conducted in April 2011, 29 soil samples were collected for texture, bulk density and water properties analysis. The soils under study were characterized by texture of silt loam with lower clay content in humus horizons ("loamy silt" according to Polish classification), and higher clay content ("clayey silt") in the illuvial and subsoil horizons. The texture of all examined profiles was dominated by the „loess” fractions. Variable abundance of the massive lamellae causes variations in water properties of the illuvial (sub-)horizons. It was found that lamellic illuvial horizons in the loess-derived Luvisols have higher field water capacity than the homogenous illuvial horizons, apart of the clay content. There was no apparent effect of the horizon kind (homogeneous versus lamellic) on the soil bulk density. These properties mainly depended on the total clay content in a particular horizon (sub-horizon).
\end{abstract}

Key words: Luvisols, water properties, lamellae illuvial horizon, homogenous illuvial horizon

\section{INTRODUCTION}

Luvisols cover over $5 \mathrm{mln} \mathrm{km}^{2}$ of the Earth surface in humid temperate climate zone. These soils are mainly located in central Europe, western Russia, eastern China, North America and in the Mediterranean area (Bockheim and Gennadiyev 2000). According to various estimates in Poland, Luvisols cover at least $40 \%$ of land surface and occur in all geographic regions except for mountainous areas (Bednarek and Prusinkiewicz 1997). Luvisols derived from silty materials are known e.g. from the Lublin Upland, the Zachodniowołyńska Upland, the Roztocze Gorajskie, the Małopolska Upland, the Silesian Lowlands, the Sudetes Foreland and the Carpathian Foothills (Klimek 2005; Turski and Słowińska-Jurkiewicz 1994; Zaleski et al. 2003; Zaleski 2012), as well as from the Błońsko-Sochaczewska plain (Chojnicki 1993). Genesis of Luvisols is related to lessivage process that involves a substantial vertical transfer of fine colloidal clay particles from surface to subsurface horizons (Driessen et al. 2001; Jaworska and Dąbkowska-Naskręt 1999). The process results in a differentiation of the soil profile on eluvial and illuvial horizons. Enrichment of B-horizon in clay fraction is observed as clay films on surface of soil aggregates, coarser pores or soil channels (Konecka-Betley and Zagórski
1994). The diagnostic horizon for Luvisols is an argic illuvial horizon. Typical "homogeneous argic horizon" is characterized by the gradual increase of clay content at the interface between $\mathrm{E}$ and Bt horizons. The other form - "lamellic argic horizon" is a result of pedogenic concentration of the clay fraction in the clearly separated horizontal layers (lamellae) of variable thickness (Driessen et al. 2001).

Luvisols derived from loess are considered soils with exceptionally favorable hydro-physical properties (Turski and Witkowska-Walczak 2004), conditioned mainly by texture, structure of porosity and mineral composition of the colloidal fraction. Because of the high retention capacity for the plant-available water, Luvisols have a great importance in agriculture. Because of this, the silt-textured Luvisols that are widespread in the Lower Silesia, were the subject of many previous studies (e.g. Borkowski 1966; Chodak 1980; Licznar and Drozd 1988; Kabała and Marzec 2010). However, the characterization of water properties concerned only Luvisols with typical (homogeneous) illuvial horizon. There is no information about physical and water properties of loess derived Luvisols with lamellic illuvial horizons in the available polish literature involving soil science.

The aim of the present work was to characterize the water retention in the silt-textured Luvisols with 
lamellic illuvial horizon (argic) that occur in the loess covered northern part of the Silesian Lowland.

\section{MATERIAL AND METHODS}

Soil pits were localized on the Trzebnica Hills delimiting the north-eastern border of Silesian Lowland. Trzebnica Hills are part of end-moraine hills indicating a maximum range of the Warta (Riss) glaciation. The contemporary area of hills is covered with late-Pleistocene loess material with the thickness of up to 8 meters. Loess decalcification in the Trzebnica Hills generally is not deep, and it does not exceed 2-3 meters (Jary et al. 2002; Jary 2002). Mean annual air temperature in the study area is $9.5^{\circ} \mathrm{C}$, and the mean annual precipitation is 500 to $620 \mathrm{~mm}$. The area is located in the border zone between positive and negative climatic water balance (Dubicki et al. 2002). Soil profiles were localized near the villages: Machnice (profile 1), Skarszyn (profile 2) and Zaprężyn (profile 3 and 4). Profiles Machnice 1 and Skarszyn 2 were situated in the upper parts of the hills covered with beech stands with an admixture of oak, linden and maple. Profiles Zaprężyn 3 and 4 were situated in the central and lower parts of the arable slope.

Soil morphology was described according to Guidelines for Soil Description (2006). Classification of soils was established using Polish Soil Taxonomy (Komisja V Genezy, Klasyfikacji i Kartografii Gleb PTG 2011) and the FAO-WRB classification (IUSS Working Group WRB 2007). In each of the distinguished soil horizons were collected the disturbed and undisturbed samples. Particle-size distribution of the $\leq 2 \mathrm{~mm}$ fraction, after sample dispersion with heksametaphosphate-bicarbonate, was conducted using sand separation on sieves and the hydrometer method for silt and clay fractions, according to the official standard PN-R-04032. The names of texture classes were given in line with the Polish Soil Science Society classification (Polskie Towarzystwo Gleboznawcze 2009). Undisturbed soil samples were collected in stainless steel rings $\left(100 \mathrm{~cm}^{3}\right)$ for the bulk density and water properties determination. Water retention was assessed for $\mathrm{pF}$ value ranges from $\mathrm{pF} 0$ to $\mathrm{pF} 2.7$ by using a sand block $(0-2.0 \mathrm{pF})$ and kaolin-sand block (2.2-2.7 pF). The organic carbon was determined in disturbed samples by dry combustion method with absorption of $\mathrm{CO}_{2}$ using Stroelein CS MAT 5500.

Due to low number of cases (only four profiles) no specific statistical analysis was done, only the Pearson correlation coefficients $($ at $p<0.05)$ were calculated for the entire set of samples using Statistica 10 package.

\section{RESULTS AND DISSCUSION}

\author{
Morphology and classification \\ of the soils studied
}

The soils studied belonged to the same soil type and reference group (according to FAO-WRB). They are characterized by similar texture and physicochemical properties. The surface horizons in the profile 1 and 2 are characterized by silt loam texture (clay content $<12 \%$ ), other distinguished soil horizons have higher clay content $(>12 \%)$ and belonged to silt loam texture class (Polskie Towarzystwo Gleboznawcze 2009). Soil profiles under beech stands have an arrangement of soil horizons: A-Et-Bt-BC-Ck typical of "natural" Luvisols (Komisja V Genezy, Klasyfikacji i Kartografii Gleb PTG 2011), with weakly developed humus horizon and well preserved eluvial horizon. Eluvial horizon gradually passes into illuvial horizon, which is homogeneous in the upper part, whereas in the lower part clearly differentiated into dense and dark lamellae (7-30 mm thick). Lamellae have sharp upper boundary and diffused bottom, and are separated by light-colored layers of loess with clearly lower clay content. According to the Polish Soil Classification (Komisja V Genezy, Klasyfikacji i Kartografii Gleb PTG 2011) both profiles represented "gleby płowe typowe" with very weakly developed redox features. According to FAOWRB (IUSS Working Group WRB 2007), the soils belonged to the reference group of Luvisols, and after taking into account the relevant qualifiers, to Albic Cutanic Lamellic Luvisols (Siltic). Arable soils (profiles Zaprężyn 3 and 4) have deep or very deep (colluvial) humus horizon with clear features of secondary development into the cambic horizon in their lower parts. Eluvial horizons in these profiles are fragmentarily preserved or absent. Lamellic illuvial horizon in the profile Zaprężyn 3 lays under „homogeneous” transitional horizon $\mathrm{EB}$, and directly below $\mathrm{AB}$ horizon in the profile Zaprężyn 4. According to the Polish Soil Classification (Komisja V Genezy, Klasyfikacji i Kartografii Gleb PTG, 2011), the profiles Zaprężyn 3 and 4 were classified as "gleby płowe z cechami brunatnienia" that is, according to FAO-WRB (IUSS Working Group WRB 2007), a close equivalent of Cutanic Lamellic Luvisol (Colluvic, Siltic) in a profile Zaprężyn 3 and Lamellic Luvisol (Siltic) in a profile Zaprężyn 4. 
Basic soil properties of the soils studied

The soils under study were characterized by texture of silt loam with lower clay content in humus horizons ("loamy silt" according to Polish classification), and higher clay content ("clayey silt") in the illuvial and subsoil horizons. The texture of all examined profiles was dominated by the ,loess" fractions. The percentage of coarse silt $(0.05-0.02 \mathrm{~mm})$ ranged between 30 and $46 \%$, and the fine silt $(0.02-0.002 \mathrm{~mm})$ ranged between 15 and $27 \%$ (Table 1). The content of fine silt was higher in the surface horizons and decreased with depth, inversely to very fine sand $(0.1-0.05 \mathrm{~mm})$ that increased in the deeper part of soil profile. All profiles had clay-enriched illuvial horizons. However, the maximum clay content was in different sub-horizons: in lamellic sub-horizon (profiles Skarszyn 2 and Zaprężyn 3) or in transitional EB and homogenous Bt sub-horizons (profile Machnice 1). In the profile Zaprężyn 4, the highest content of clay was found in $\mathrm{A}$ and $\mathrm{AB}$ horizons, formed probably from the plowed upper part of homogenous Bt horizon. This profile may be considered as eroded equivalent of the profile Machnice 1. The texture of particular strata in the lamellic B/C horizon (as in profile Zaprężyn 4) clearly differed each other (Table 1). Darker lamellae contained less coarse silt and very fine sand but $4 \%$ more clay than lighter inter-lamellae loess strata. The relative difference in clay content between these strata reached $30 \%$.

Bulk density of undisturbed soil varied in a wide range of values between 1.09 and $1.61 \mathrm{~g} \cdot \mathrm{cm}^{-3}$ (Table 2). The lowest values were recorded in humus horizons $\left(1.09-1.36 \mathrm{~g} \cdot \mathrm{cm}^{-3}\right)$, due to negative relationship to organic carbon (Table 3), with the exception of profile Zaprężyn 4, where the high bulk density $\left(1.47-1.53 \mathrm{~g} \cdot \mathrm{cm}^{-3}\right)$ resulted from plowing the upper part of Bt horizon. The other specific phenomena, the ,plow sole" in subsurface AB horizon $\left(1.48 \mathrm{~g} \cdot \mathrm{cm}^{-3}\right)$ was found in

TABLE 1. Particle-size distribution

\begin{tabular}{|c|c|c|c|c|c|c|c|c|c|c|c|}
\hline \multirow[t]{2}{*}{ Profile } & \multirow[t]{2}{*}{ Horizon } & \multirow[t]{2}{*}{$\begin{array}{l}\text { Depth } \\
\text { (cm) }\end{array}$} & \multicolumn{9}{|c|}{$\begin{array}{l}\text { Particle size distribution } \\
(\%)\end{array}$} \\
\hline & & & $>2$ & $2-1$ & $1-0.5$ & $0.5-0.25$ & $0.25-0.1$ & $0.1-0.05$ & $0.05-0.02$ & $0.02-0.005$ & $<0.002$ \\
\hline \multicolumn{12}{|c|}{ Gleba płowa typowa/Albic Cutanic Lamellic Luvisol (Siltic) } \\
\hline \multirow[t]{7}{*}{ Machnice 1} & $\mathrm{AE}$ & $0-10$ & 0 & 0,5 & 1 & 2 & 3,5 & 17 & 41 & 25 & 10 \\
\hline & $\mathrm{Et}$ & $10-24$ & 0 & 0,5 & 0,5 & 1 & 2 & 18 & 39 & 26 & 13 \\
\hline & $\mathrm{EB}$ & 24-33 & 0 & 0 & 1 & 1 & 1 & 15 & 39 & 24 & 19 \\
\hline & $\mathrm{Bt}$ & $33-60$ & 0 & 0 & 1 & 1 & 1 & 17 & 39 & 20 & 21 \\
\hline & $\mathrm{B} / \mathrm{C} 1 *$ & $60-85$ & 0 & 0 & 0 & 1 & 1 & 30 & 30 & 21 & 17 \\
\hline & $\mathrm{B} / \mathrm{C} 2 *$ & $95-145$ & 0 & 0 & 0 & 1 & 1 & 26 & 35 & 20 & 17 \\
\hline & C & $145-180$ & 0 & 0 & 0 & 1 & 2 & 17 & 44 & 21 & 15 \\
\hline \multicolumn{12}{|c|}{ Gleba płowa typowa/Albic Cutanic Lamellic Luvisol (Siltic) } \\
\hline \multirow[t]{8}{*}{ Skarszyn 2} & $\mathrm{AE}$ & $0-6$ & 0 & 0 & 1 & 1 & 2 & 19 & 44 & 26 & 7 \\
\hline & Et & $6-19$ & 0 & 0 & 1 & 1 & 2 & 17 & 45 & 26 & 8 \\
\hline & EB1 & 19-29 & 0 & 0 & 1 & 1 & 1 & 16 & 45 & 24 & 12 \\
\hline & EB2 & $29-42$ & 0 & 0 & 0 & 1 & 1 & 18 & 42 & 20 & 18 \\
\hline & Btg & $42-60$ & 0 & 0 & 0 & 1 & 1 & 16 & 40 & 21 & 21 \\
\hline & $\mathrm{Bt}^{*}$ & $60-105$ & 0 & 0 & 0 & 1 & 1 & 16 & 39 & 22 & 21 \\
\hline & $\mathrm{B} / \mathrm{C}^{*}$ & $105-120$ & 0 & 0 & 0 & 1 & 1 & 20 & 40 & 24 & 14 \\
\hline & $\mathrm{Ck}$ & $120-170$ & 0 & 0 & 1 & 1 & 1 & 18 & 41 & 22 & 16 \\
\hline \multicolumn{12}{|c|}{ Gleba płowa z cechami brunatnienia/Cutanic Lamellic Luvisos (Colluvic, Siltic) } \\
\hline \multirow[t]{6}{*}{ Zaprężyn 3} & Ap & $0-24$ & 0 & 0 & 1 & 1 & 2 & 13 & 42 & 27 & 14 \\
\hline & $\mathrm{AB}$ & $24-60$ & 0 & 0 & 1 & 1 & 1 & 17 & 39 & 27 & 14 \\
\hline & $\mathrm{EB}$ & $60-82$ & 0 & 0 & 1 & 1 & 2 & 15 & 39 & 26 & 16 \\
\hline & $\mathrm{Bt}^{*}$ & $82-115$ & 0 & 0 & 0 & 1 & 1 & 15 & 40 & 25 & 18 \\
\hline & Btg* & $115-160$ & 0 & 0 & 0 & 0 & 1 & 21 & 38 & 21 & 19 \\
\hline & $\mathrm{B} / \mathrm{C}$ & $160-200$ & 0 & 0 & 0 & 0 & 2 & 23 & 43 & 17 & 15 \\
\hline \multicolumn{12}{|c|}{ Gleba płowa z cechami brunatnienia / Lamellic Luvisol (Siltic) } \\
\hline \multirow[t]{8}{*}{ Zaprężyn 4} & Ap & $0-16$ & 0 & 0 & 0 & 1 & 2 & 16 & 39 & 22 & 20 \\
\hline & $\mathrm{AB}$ & $16-42$ & 0 & 0 & 0 & 1 & 1 & 16 & 39 & 23 & 20 \\
\hline & $\mathrm{Bt} 1 *$ & $42-60$ & 0 & 0 & 1 & 1 & 1 & 16 & 39 & 25 & 17 \\
\hline & $\mathrm{Bt} 2 *$ & $60-82$ & 0 & 0 & 0 & 0 & 1 & 16 & 43 & 23 & 17 \\
\hline & $\mathrm{B} / \mathrm{C}^{*}$ & $82-140$ & 0 & 0 & 0 & 1 & 2 & 19 & 45 & 18 & 15 \\
\hline & $\mathrm{C}$ & $140-170$ & 0 & 0 & 0 & 1 & 5 & 24 & 41 & 15 & 14 \\
\hline & inter-lamella & $121-126$ & 0 & 0 & 0 & 1 & 2 & 22 & 45 & 16 & 14 \\
\hline & lamella & $126-128$ & 0 & 0 & 0 & 2 & 3 & 19 & 40 & 18 & 18 \\
\hline
\end{tabular}

Explanation: * lamellic Bt horizon. 
the profile Zaprężyn 3. This value was higher than in directly overlying and underlying horizons. Bulk density of illuvial horizons ranged between 1.42 and $1.61 \mathrm{~g} \cdot \mathrm{cm}^{-3}$, mostly above $1.50 \mathrm{~g} \cdot \mathrm{cm}^{-3}$. It was found that the bulk density distribution throughout the illuvial horizon does not depend on the horizon kind (lamellic or homogeneous), but on the clay content in subsequent sub-horizons. The highest bulk density in the profiles Skarszyn 2 and Zapreżzyn 3 was observed in the lamellic sub-horizons. In the profile Machnice 1, the highest bulk density were observed in the homogeneous subhorizon, due to the highest clay content. The bulk density of lamellae and inter-lamellae strata has not been measured separately. Probably the bulk density of the lamellae will be higher than $1.65 \mathrm{~g} \mathrm{~cm}^{-3}$, if an ranged between 42.2 and $55.9 \%$ (by soil volume) (Table 2), and both the highest and the lowest moistures at $\mathrm{pF}=0$ were measured in the humus horizons. The soil water capacity in the surface horizons was not related to the land use, as differences in water content were found between pairs of profiles under the same vegetation (soils 1-2 and 3-4). The soil moisture (at $\mathrm{pF}=0$ ) in the lamellic illuvial sub-horizons ranged between 45.5 and $51.4 \%$; increasing or decreasing with depth depending of soil profile. Diversity of the maximum capacity (at $\mathrm{pF}=0$ ) in the lamellic illuvial sub-horizons is much less than in the humus and eluvial horizons. No clear relation was observed in the maximum water capacity between lamellic and homogeneous illuvial sub-horizons. Although in the profiles

TABLE 2. Water properties of studied soils with regard to bulk density and organic carbon content

\begin{tabular}{|c|c|c|c|c|c|c|c|c|c|c|}
\hline \multirow[t]{2}{*}{ Soil profile } & \multirow[t]{2}{*}{ Horizon } & \multirow{2}{*}{$\begin{array}{l}\text { Depth } \\
\text { (cm) }\end{array}$} & \multirow{2}{*}{$\begin{array}{l}\text { Bulk density } \\
\left(\mathrm{g} \mathrm{cm}^{-3}\right)\end{array}$} & \multirow{2}{*}{$\begin{array}{l}\text { Organic } \\
\text { carbon } \\
\left(\mathrm{g} \mathrm{kg}^{-1}\right)\end{array}$} & \multicolumn{6}{|c|}{$\mathrm{pF}(\% \mathrm{v} / \mathrm{v})$} \\
\hline & & & & & 0 & 1.0 & 2.0 & 2.2 & 2.5 & 2.7 \\
\hline \multirow[t]{6}{*}{ Machnice 1} & $\mathrm{Et}$ & $10-24$ & 1.33 & 9.7 & 53.8 & 50.2 & 41.2 & 35.5 & 35.0 & 33.0 \\
\hline & $\mathrm{EB}$ & $24-33$ & 1.37 & 6.2 & 52.5 & 50.7 & 40.4 & 33.2 & 26.7 & 24.9 \\
\hline & $\mathrm{Bt}$ & $33-60$ & 1.55 & 3.2 & 48.4 & 46.5 & 36.8 & 34.1 & 27.7 & 24.6 \\
\hline & $\mathrm{B} / \mathrm{C} 1 *$ & $60-85$ & 1.53 & 1.7 & 46.2 & 44.6 & 41.1 & 39.2 & 34.8 & 31.6 \\
\hline & $\mathrm{B} / \mathrm{C} 2 *$ & $85-145$ & 1.52 & 1.2 & 47.0 & 44.9 & 40.4 & 38.1 & 35.1 & 30.6 \\
\hline & $\mathrm{C}$ & $145-180$ & 1.50 & 1.1 & 47.2 & 45.7 & 39.7 & 36.2 & 27.8 & 25.2 \\
\hline \multirow[t]{7}{*}{ Skarszyn 2} & $\mathrm{Et}$ & $6-19$ & 1.36 & 10.5 & 45.5 & 44.2 & 39.9 & 35.7 & 30.3 & 25.4 \\
\hline & EB1 & $19-29$ & 1.39 & 6.7 & 45.7 & 44.0 & 38.7 & 35.3 & 32.7 & 25.8 \\
\hline & EB2 & $29-42$ & 1.54 & 6.5 & 47.3 & 45.7 & 40.9 & 38.5 & 34.0 & 30.6 \\
\hline & Btg & $42-60$ & 1.58 & 3.1 & 42.9 & 416 & 38.9 & 38.1 & 34.4 & 32.0 \\
\hline & $\mathrm{Bt}^{*}$ & $60-105$ & 1.60 & 3.8 & 46.0 & 44.2 & 41.2 & 40.0 & 37.2 & 33.8 \\
\hline & $\mathrm{B} / \mathrm{C}^{*}$ & $105-120$ & 1.48 & 2.9 & 48.3 & 47.3 & 41.4 & 39.0 & 34.3 & 28.7 \\
\hline & $\mathrm{Ck}$ & $120-170$ & 1.54 & 2.1 & 51.4 & 47.6 & 42.9 & 39.8 & 35.3 & 30.8 \\
\hline \multirow[t]{6}{*}{ Zaprężyn 3} & $\mathrm{Ap}$ & $0-24$ & 1.09 & 15.0 & 55.9 & 52.8 & 36.9 & 31.9 & 30.7 & 26.3 \\
\hline & $\mathrm{AB}$ & $24-60$ & 1.48 & 10.2 & 44.6 & 43.2 & 39.8 & 36.1 & 35.2 & 32.7 \\
\hline & $\mathrm{EB}$ & $60-82$ & 1.30 & 9.3 & 51.5 & 49.5 & 37.8 & 35.2 & 30.1 & 26.8 \\
\hline & $\mathrm{Bt}^{*}$ & $82-115$ & 1.52 & 2.7 & 51.4 & 48.9 & 41.0 & 39.1 & 35.3 & 26.5 \\
\hline & Btg* & $115-160$ & 1.61 & 0.7 & 45.4 & 43.8 & 41.0 & 39.1 & 34.9 & 32.5 \\
\hline & $\mathrm{B} / \mathrm{C}^{*}$ & $160-200$ & 1.48 & 0.5 & 49.6 & 45.9 & 42.2 & 39.2 & 37.3 & 36.2 \\
\hline \multirow[t]{6}{*}{ Zaprężyn 4} & Ap & $0-16$ & 1.47 & 11.2 & 46.1 & 44.5 & 38.8 & 36.6 & 34.3 & 32.6 \\
\hline & $\mathrm{AB}$ & $16-42$ & 1.53 & 8.8 & 42.2 & 40.7 & 37.9 & 36.2 & 34.0 & 31.3 \\
\hline & $\mathrm{Bt1}{ }^{*}$ & $42-60$ & 1.46 & 3.8 & 47.3 & 44.9 & 40.3 & 38.3 & 32.7 & 30.0 \\
\hline & $\mathrm{Bt} 2 *$ & $60-82$ & 1.42 & 1.3 & 48.7 & 47.1 & 40.4 & 38.2 & 33.6 & 27.2 \\
\hline & $\mathrm{BtC}^{*}$ & $82-140$ & 1.53 & 0.7 & 51.4 & 49.1 & 44.3 & 41.9 & 35.9 & 30.1 \\
\hline & $\mathrm{C}$ & $140-170$ & 1.37 & 0.5 & 54.5 & 50.0 & 43.9 & 40.9 & 34.9 & 30.3 \\
\hline
\end{tabular}

Explanation: * lamellic Bt horizon.

average bulk density of the entire lamellic horizons reached $1.60 \mathrm{~g} \mathrm{~cm}^{-3}$. Gradual decrease of the bulk density was expected in the bottom part of the illuvial horizons due to decreasing number of lamellae and clay content. This rule was true in the profiles Machnice 1 and Zaprężyn 4. However, the accumulation of the secondary carbonates, as in the profile Skarszyn 2, affected the structure of loess and caused the bulk density raise in the bottom part of Bt horizon comparable with the effect of clay accumulation. The recorded bulk density values are in the wide range of values reported in the previous studies on Luvisols derived from silt materials (Chodak 1980; Klimek 2005; Licznar and Drozd 1988; Turski and Witkowska-Walczak 2004; Zaleski 2012).

\section{Water properties of the soils studied}

The water properties differed greatly within the profiles of Luvisols under study, but not as much as in the Luvisols with the sharp lithological discontinuity (Komisarek and Szalata 2008). The soil moisture corresponding to the maximum water capacity $(\mathrm{pF}=0)$ 
2 and 4 the highest water capacity was in the homogeneous sub-horizons and decreased with depth, in the profiles 1 and 3 , inversely, the water capacity was higher in the lamellic sub-horizons or differed from the homogeneous sub-horizons (Figure).

Water capacity at $\mathrm{pF}=2.2$ in all the analyzed genetic horizons varied minimally in eluvial horizons of forest soils $-33.2-35.7 \%$, in homogeneous illuvial horizons $-34.1-38.1 \%$, and in lamellic illuvial horizons $-38.1-$ $40.0 \%$ (in one case to $41.9 \%$ ) (Table 2). In all profiles the field capacity in the lamellic sub-horizons was higher than in the homogeneous sub-horizons apart of the clay content (Figure). Worth noting is a rule that the field capacity of the homogeneous illuvial sub-horizons was always higher than this in the humus and eluvial horizons. Field water capacity increased in the deepest horizons (parent material). Due to the higher values of bulk density in this horizons (Table 3 ).

The water capacity at $\mathrm{pF}=2.7$ was, in general, similar or varying in the same range in the illuvial sub-horizons of various kind. Only in the forest Luvisols, the water capacity at $\mathrm{pF}=2.7$ was in the homogeneous
TABLE 3. Coefficients of Pearson correlation for the entire data set (coefficients significant at $\mathrm{p}<0.05$ are marked with $*$ )

\begin{tabular}{llccccc}
\hline & Corg & $\mathrm{pF} \mathrm{0}$ & $\mathrm{pF} \mathrm{2.2}$ & $\mathrm{pF} \mathrm{2.7}$ & silt & clay \\
\hline $\mathrm{dv}$ & $-0.63^{*}$ & $-0.62^{*}$ & $0.62^{*}$ & $0.41^{*}$ & $-0.45^{*}$ & $0.47^{*}$ \\
\hline Corg & & 0.06 & $-0.73^{*}$ & -0.15 & $0.52^{*}$ & -0.18 \\
\hline $\mathrm{pF} \mathrm{0}$ & & -0.11 & -0.24 & 0.08 & -0.29 \\
\hline $\mathrm{pF} 2.2$ & & & $0.52^{*}$ & $-0.42^{*}$ & 0.01 \\
\hline $\mathrm{pF} 2.7$ & & & & $-0.44^{*}$ & 0.15 \\
\hline silt & & & & & $-0.51^{*}$ \\
\hline
\end{tabular}

Explanation: $d_{v}$ - bulk density, Corg - organic carbon, $\mathrm{pF} 0, \mathrm{pF} 2.2, \mathrm{pF} 2.7$ - water capacity at given $\mathrm{pF}$ value.

illuvial sub-horizons lower than in lamellic sub-horizons (Figure).

The field water capacity $(\mathrm{pF}=2.2)$ of the humus and eluvial horizons are very similar to these reported in other papers on Luvisols derived from silt materials, as in the range 37-39\% reported by Licznar and Drozd (1988), Klimek (2005), and Zaleski (2012). In the Bt horizons, recorded values were higher than given in available literature on Luvisols. However, in these
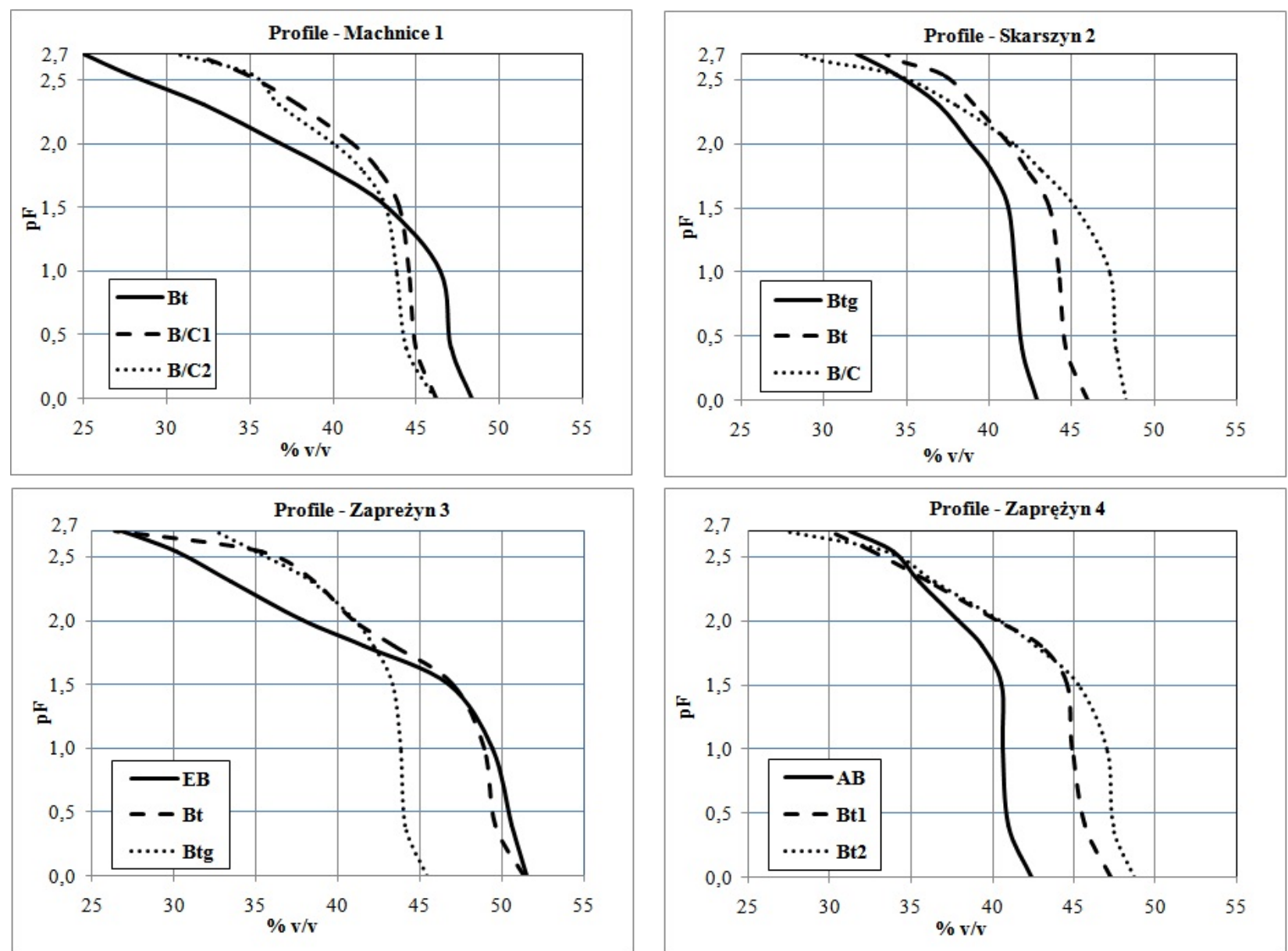

FIGURE. Water desorption curves ( $\mathrm{pF}$ curves) for illuvial sub-horizons: (solid line) - homogenous illuvial horizons, (dashed line) upper lamellic illuvial horizon, (dotter line) - bottom illuvial horizon (transitional to the parent material 
papers, in general, the kind of illuvial horizon (lamellic or homogenous) was not distinguished. Water field capacity of the illuvial horizons in soils of the Carpathian Foothills ranged between 31.0 and $37.2 \%$ (Zaleski et al. 2006; Zaleski 2012). Also in the loess-derived Luvisols in the Glubczyce Plateu, the water field capacity was around 33.2-36.2\% (Licznar and Drozd 1988). Only Klimek (2005) reported higher field capacity of illuvial horizons, ranging between 38 and $40 \%$, similar to this recorded in the upper homogeneous illuvial sub-horizons of soils in the Trzebnickie Hills. All cited papers confirmed that silt-textured Luvisols have higher water content (for values above $\mathrm{pF}=2.0$ ) in the subsoil $(\mathrm{Bt}+\mathrm{B} / \mathrm{C})$ than in the upper part $(\mathrm{A}+\mathrm{E})$ of the soil profile.

Although the results come from the initial stage of study and need to be verified in a larger number of soil profiles, it is already possible to indicate some regularity. In the examined soils, a homogeneous illuvial Bt horizon gradually passes into lamellic $\mathrm{Bt}$ horizon. In this horizon, abundance and thickness of lamellae decrease gradually with depth. Fine-textured lamellae contain few percent more clay than inter-lamellae loess strata. Relative difference in clay content may reach $30 \%$, which explains differences in the structure and massiveness of the strata. Lamellae have very strong angular-platy structure, while the loess interlamellae strata are poorly angular structure. Variable abundance of the massive lamellae causes the variations in physicochemical and water properties of the illuvial (sub-) horizons. There was no apparent effect of the kind of horizon (homogeneous versus lamellic) on the bulk density and the maximum water capacity. These properties mainly depended on the total clay content in a particular horizon (sub-horizon). However, it was found that lamellic illuvial horizons in the loess-derived Luvisols have higher field water capacity than the homogenous illuvial horizons, apart from the clay content.

\section{CONCLUSIONS}

1. Total amount of clay, but not the kind of an illuvial horizon (homogeneous versus lamellic) is main factor determining the bulk density of illuvial horizon in loess-derived Luvisols.

2. Kind of illuvial (sub-)horizon (homogeneous or lamellic) does not affect the maximum water capacity of the illuvial horizon.

3. Illuvial lamellic horizons have higher field water capacity (at $\mathrm{pF}=2.2$ ) than homogeneous illuvial horizons of loess-derived Luvisols.

\section{ACKNOWLEDGMENT}

The study was financed by the National Science Centre (research grant No. 2012/05/B/NZ9/03389).

\section{REFERENCES}

Bednarek R., Prusinkiewicz Z., 1997. Geografia gleb. PWN, Warszawa (In Polish).

Bockheim J.G., Gennadiyev A.N., 2000. The role of soil-forming processes in the definition of taxa in soil taxonomy and the world soil reference base. Geoderma, 95: 53-72.

Borkowski J., 1966. Gleby brunatne Sudetów. Zeszyty Komitetu Zagospodarowania Ziem Górskich PAN, 12: 29-93 (In Polish).

Chodak T., 1980. Badania nad właściwościami oraz składem mineralnym gleb wytworzonych z lessu Dolnego Śląska. Zesz. Nauk. AR Wrocław, 21: 1-49 (In Polish).

Chojnicki J., 1993. Gleby płowe wytworzone z utworów pokrywowych równiny Błońsko-Sochaczewskiej. Roczniki Gleboznawcze - Soil Sciecne Annual, 44(3/4): 135-151 (In Polish).

Driessen P., Deckers J., Spaargaren O., 2001. Lecture notes on the major soils of the world. World Soil Resources Reports 94, FAO, Rome.

Dubicki A., Dubicka M., Szymanowski M., 2002. Klimat Wrocławia. [In:] Środowisko Wrocławia - Informator 2002. Dolnośląska Fundacja Ekorozwoju, Wrocław 9-25 (In Polish).

Guidelines for soil description., 2006. 4rd Edition, FAO, Rome. IUSS 2006. World Reference Base for Soil Resources 2006. 2nd edition, World Soil Resources Reports 103, FAO, Rome.

IUSS Working Group WRB, 2007. World Reference Base for Soil Resources 2006. First update 2007. World Soil Resources Reports, 103. FAO, Rome.

Jary Z., Kida J., Śnihur M., 2002. Lessy i osady lessopochodne w południowo-zachodniej Polsce. Czasopismo Geograficzne, 73(1-2): 63-100 (In Polish).

Jary Z., 2002. Zapis zmian klimatu w górnoplejstoceńskich sekwencjach lessowo-glebowych w Polsce i w zachodniej części Ukrainy. Rozprawy Naukowe Instytutu Geografii i Rozwoju Regionalnego Uniwersytetu Wrocławskiego 1, Wrocław, 136 pp. (In Polish).

Jaworska H., Dąbkowska-Naskręt H., 1999. Gleby płowe wytworzone z utworów pyłowych Pojezierza Chełmińsko-Dobrzyńskiego i Wysoczyzny Kaliskiej. Roczniki Gleboznawcze - Soil Sciecne Annual, 50(1/2): 97-114 (In Polish).

Kabała C., Marzec M., 2010. Profilowe i przestrzenne zróżnicowanie uziarnienia gleb płowych wytworzonych $\mathrm{z}$ lessów w południowo-zachodniej Polsce. Roczniki Gleboznawcze-Soil Sciecne Annual, 61(3): 52-64 (In Polish).

Klimek M., 2005. Pedogenetyczne uwarunkowania retencyjności pokryw pyłowych progu Pogórza Karpackiego. Roczniki Gleboznawcze - Soil Sciecne Annual, 56(1/2): 85-96 (In Polish).

Komisarek J., Szałata S., 2008. Zróżnicowanie uziarnienia w profilach gleb płowych zaciekowych z obszaru Wielkopolski. Nauka Przyroda Technolgie, 2(2): 1-14 (In Polish).

Komisja V Genezy, Klasyfikacji i Kartografii Gleb PTG, 2011. Systematyka Gleb Polski, wyd. 5, Roczniki GleboznawczeSoil Science Annual, 62(3): 1-193 (In Polish).

Konecka-Betley K., Zagórski Z., 1994. Wpływ interglacjalnych procesów glebotwórczych na cechy mikromorfologiczne gleb kopalnych wytworzonych z lessów. Roczniki Gleboznawcze - Soil Sciecne Annual, 45(3/4): 85-95 (In Polish). 
Licznar M., Drozd J., 1988. Wpływ rzeźby terenu na zmiany właściwości szarych gleb leśnych Płaskowyżu Głubczyckiego w wyniku erozji. Roczniki Gleboznawcze - Soil Science Annual, 39(4): 35-56 (In Polish).

Polskie Towarzystwo Gleboznawcze, 2009. Particle size distribution and textural classes of soils and mineral materials classification of Polish Society of Soil Science 2008. Roczniki Gleboznawcze - Soil Science Annual, 60(2): 5-16 (In Polish).

Turski R., Słowińska-Jurkiewicz A., 1994. Gleby wytworzone z lessów. Lubelskie Towarzystwo Naukowe, Lublin, 65 pp. (In Polish).

Turski M., Witkowska-Walczak B., 2004. Fizyczne właściwości gleb płowych wytworzonych z utworów pyłowych różnej genezy. Acta Agrophysica, 101, 56 pp. (In Polish).
Zaleski T., Klimek M., Głąb T., 2003. Porównanie zwięzłości różnie użytkowanych gleb płowych Pogórza Wielickiego. Zeszyty Problemowe Postępów Nauk Rolniczych, 493: 555562 (In Polish).

Zaleski T., Kacprzak A., Maj K., 2006. Pedogenetic conditions of retention and filtration in soils fordem from slope covers on the example of a selected catena in the Pieniny Mts. Polish Journal of Soil Science, 39(2): 185-195.

Zaleski T., 2012. Rola pedogenezy w kształtowaniu właściwości hydrofizycznych, retencji, reżimu i bilansu wodnego gleb wytworzonych z utworów pyłowych Karpat. Zeszyty Naukowe UR w Krakowie. 494, 114 pp. (In Polish).

Received: January 14, 2014

Accepted: Aprill, 2014

\section{Właściwości retencyjne lessowych gleb płowych z lamelowym poziomem iluwialnym z obszaru Wzgórz Trzebnickich}

Strzeszczenie: Badane profile gleb płowych wytworzonych z lessów zlokalizowane zostały na Wzgórzach Trzebnickich, które od północnego-wschodu zamykają obszar Niziny Śląskiej. Profile Machnice 1 i Skarszyn 2 zlokalizowane zostały w grzbietowych partiach wzniesień pod drzewostanami bukowymi z domieszką dębu, lipy oraz klonu. Profile Zaprężyn 3 i 4 położone są w środkowej i dolnej części stoku na polach ornych. Łącznie w trakcie prac terenowych w kwietniu 2011 roku pobrano 29 próbek glebowych. W pobranym materiale analitycznym oznaczono skład granulometryczny, gęstość objętościową oraz właściwości wodne na podstawie krzywej pF. Celem pracy była charakterystyka właściwości retencyjnych pyłowych gleb płowych z lamelowym poziomem iluwialnym (argic). Badania wykazały, że zmienny udział masywnych lamel powoduje zróżnicowanie analizowanych właściwości wodnych poziomu iluwialnego. Lamelowe podpoziomy iluwialne w badanych lessowych glebach płowych mają większą polowa pojemność wodna niż homogeniczne podpoziomy iluwialne, niezależnie od zawartości iłu. Nie stwierdzono wyraźnego wpływu rodzaju poziomu iluwialnego (homogeniczny lub lamelowy) na gęstość objętościową gleby, która w większym stopniu zależna jest od zawartości frakcji ilastej.

Słowa kluczowe: gleby płowe, właściwości wodne, lamelowy poziom iluwialny, homogeniczny poziom iluwialny 